\title{
The Oxidizing Enzymes of Sugareane: Tyrosinase (Polyphenol oxidase)
}

\author{
Alex $G$. Alexander
}

IVTRODUCTION

When, in 1931, Sommer (57) ${ }^{2}$ published the first convincing evidence of copper essentiality for higher plants, there was no inkling that this metal took pare in distinct cellular functions, or that it could bo a const inum of oxidizing enzymes. Indeed, for more then a century biologists had viewed the presene of copper in plant tissues as a kind of natural arcident, of litfle or no consequence $(8,2,4)$. Perhajs no experiments have so succincly demonstrated the physiological potential of micronutrients than those dealing with the copper proteins. Foremost among this group is the oxidizing enzyme tyrosinase.

Calialyzing the type reaction

$$
\mathrm{AH} \cdot+\mathrm{C}_{2} \stackrel{\text { oxidase }}{\longrightarrow} \mathrm{A}+\mathrm{H}_{2} \mathrm{O} \text {, }
$$

the copper-containing enzymes stimulate direst oxidation of their respective substrates by atmospheric oxygen. 'The rotetion does not lake place anaterobially. Dyes such as methylene blue are not altered by the copper enzymes, and to hydrogen peroxide formation resuls from their activity. Wath enzyme is sensitive to cyanide.

Tyrosinase was discovered by Bertrand and Bourquelot $(12,15,13)$, who demonstrated that darkening of mushinom tissues was due to the enzymatic oxilation of tyrosinc, a phenolic anino arid. ${ }^{3}$ Kubowitz $(36,37)$ hats proposed a sequence of copper-requiring reactions to account for the oxidation of a polyphent, such as citechol, to its corresponding quinone. Thus the eupric state of the enzyme is reduced to the cuprous form, which, in turn, is reoxidized by oxygen:

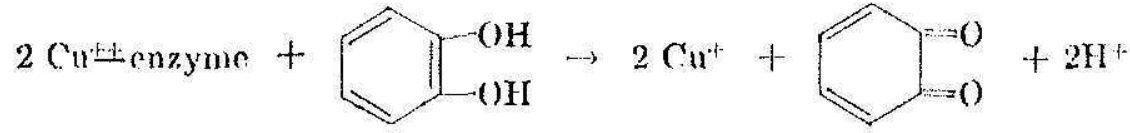

$$
\begin{aligned}
& \text { Catcuhol o-tequinone }
\end{aligned}
$$

'Associate Plant Physiologist, Agricultural Fxperiment Station, University of Puerto Rico, Río Pindus, P.R.

2 Italie numbers in parentheses refer to Literature Cited, $\mu p .127-30$.

3 The term "tyrosinase" is not a very accurate one, since a common property of the enzyme is tu catalize the oxidution of both monohydric and dihydric phennls. Henee, such nause as "cresolase," "monophonolase," "catecholase," and "polyphemoloxiduse"' have all appeared in the liternture with reference in the same nuymo. 
Copper apparently functions as a prosthetic group attached through a nonporphyrin linkage (27, p. 367). The darkening which accompanies tyrosinase action (i.e., the browning of cut or bruised tissues of fruits and vegetables) is believed due to a subsequent series of nonenzymatic reactions whereby quinones are converted to dark, molanin-like pigments $(60$, p. $241,53,4 \%, 46,45)$.

'lle marked capacity of tyrosinase to calalyze electron transior from motabolites to oxygen has led workers to suspect that this enzyme might be a key constifuent of terminal oxidation. Unfortunately, a prolonged rontroversy over this point has left fyrosinase hanging, its true roles as yel umesolved.4 Boswell and Whiting (16) telt that a catechol-like compound mighi be the natum hydrogen earrier operating aljacent to the terminal oxidase of potato. They were able to increase the oxygen uptake of potato slices by adding catechol, although later the reaction product apparently inhibited the oxidase. Baker and Nelson (9) used a substituted catechol, 4-t-butyl catechol, to show that decline of oxygen uptake did not, result from oxidase inhibition. 'They further strengthened the ease for tyrosinase as a respiratory enzyne by obtaining a prolonged oxygen uptake increase, with a concurrent increase of carbon dioxide evolution, thus mainlaining the respiration quotient close to unity. Sreerangarhar $(58,59)$ reported evidence that tyrosinase serves as a terminal oxidase in tea leaves and stems. No participation of cytochrome oxidase, another suspected catalyst of terminal oxidation, was detected (ijs). Studios by Bonner and Wildman (1/) led to similat conclusions regarling tyrosimase of spinach leaves, since more than 90 pereent of the respiration was inhibited by p-nitrophenol. This agent inhibits tyrosinase but has no eflect on the eytochrome enzymes.

Other workers have been skeptical of tyrosinase in lesplution, favoring instead the iron-containing enzyme eytorhrome oxidase." Levy and coworkers (39) observed that potato respiration is inhibited by subon monoxide, and that this inhibition is reversed by light. Brown and Goddard (17) recorded similax light efterts while working with wheat embryos, although Allen and Goddard (7) failed to deteet either carbon monoxide or light effects upon the respiration of mesophyll colls in mildewed wheat.

'For a more thorongh review of the respiratory roles al tyrosinast, the reader is rofered to the papers by Dawson and 'larploy (2/4), Nelsom (48), Arnon (8), and by ( Coddard and Meense (28).

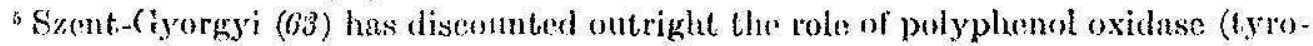
sinase) in plant rexpiration, asigning the enzyme a dormunt role in normal tissues. Aceorling to this view, only when tissues are damaged, as by bruising or pabogenic invasiom, is the enayme mobilized amd required to prextuce a guinono which is toxic (1) the invader. 
Light reversal of $\mathrm{CO}$ inhibition is a characteristic of iron-porphyrin oxidase systems, most notably that of cytochrome $\mathrm{C}$.

A perhaps more reasonable stand favors both copper and iron oxidases in plant respiration, one acting in the absence of the other, or both together, Guzman-Barron and coworkers (33) reported that 8-hydroxyquinoline completely inhibited potato polyphenol oxidase ((yrosinase), while having no effect on cytochrome oxidase. Since potato respiration was only partly inhibited by this agent, it was concluded that both enzynes take part in potato respiration. It is also inmortunt that, while carbon monoxidn inhibition may be reversed by light for ono tissue, carrot root, it may not be reversed for another, carrot leaf, of the same plant (/3). Warburg (6:4) has shown that, in the presence of polyphenol oxidase (1yrosinase), there is a coupled oxidation-reduction between redued pyridine nucleotides and polyphenols. During the discussion period following a pauper by Nelson (48) on phenol oxidases in plant respiration, the following pertinent comments on the copper and cytochrome oxidases were contributed by Dr. S. 'Granick: ${ }^{6}$

The possibility of a copper enzyme coming into play in the cytochrome oxidase, picture need not be dismissed summarily. Since one has to account for a transfer of 4 electrons from cytochrome $\mathrm{C}$ to $\mathrm{D}_{2}$ to form $2 \mathrm{H}_{2} \mathrm{O}$ and sine such aclivity is yet known only in the helerogeneous mitochondrial material, it might be that a eopper enzyme could coupcrate with eytochrome oxidase in the process of oxidation with oxygen. Furthermore, if the energy released in cytochrone $C$ oxilation is not to be. wasted, it is necessary to postulate other enzyme interactions with this oxidation. The process of ey tochrome oxidase reuction is, therefore, probably not to be regarden as a simple one enzyme activity.

It is interesting to note that Keilin and Hartree (35), Graubard (30), and Eichel el al. (26) liave all suggested that cytochrome oxidase itself may be a copper-containing enzyme.

Copper enzymes, like those of iron, have been studied as possible indicators of nutritional disorders in agricultural plants $(10,18,19,20,51,2)$. Previous work in Puerto Rico has shown that tyrosinase is present in sugarcane-leaf tissues (1). Until now, however, the enzyme has not received the close attention given to those more directly related to sugar formation and breakdown.

Tyrosinase is important in cane to the extent that it participates in respiration," including the metabolism of sucrose aceumulations and of the

${ }^{B}$ Rockefeller Institute for Medical Resenreh.

"Goddard and Meense (28) define respiration as ". . the oxidation of organic compounds with molecular oxy'gen serving th the ultimate electron aeceptor; the oxidation may be complete with water and carbon dioxide as the final products, or it may be incomplete, with organie acids as the end products." In their report an arbitrary distinetion was drawn between respitution and glycolysis, although in 
hexose and phosphorylated metabolites which otherwise would have taken part in sucrose formation. In view of present concepts of crminal oxidation, cither tycosinase or cytochrome oxidase, separately or logether, must serve as most critical factors during carbohydrate breakdown. This paper deals with the distribution and properties of canc tyrosinnse as an additional st(p) toward clarifying oxidase-sucrose relationships iu stgareane.

\section{MATERIALS A.ND METIOOS}

Tyrosimase was obtained from meristem tissue of the sugarulle varicty

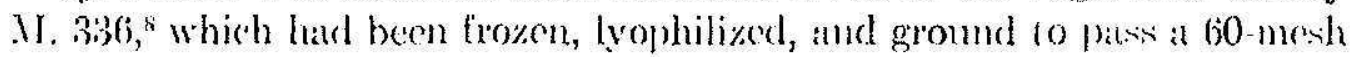

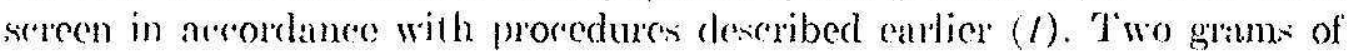

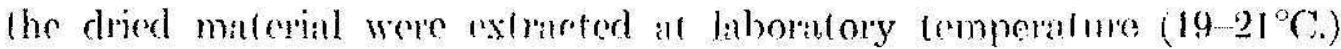
for 30 ninules in distilled water or 0.1 . . $^{3}$ phosphate buffer, pH 7 . Fximation was aided with a mechanical shaker operating at high speed. Extracts were rlarified by expression through four layers of absorbent gauze, follow'ed by centrifuging at $3,000 \mathrm{r}$.j).m.

After adjusting the $\mathrm{pH}$ to 7 with $0.25 \mathrm{~N}$ NaOH, sufficient solid ammonium sulfate was added to bring the solution to 80 -percent. satuation. This was ac'omplishel over a 10 -minute period with constant stiring of the solution. Precipitaled protein was laken up in $t$ ml. of distilled water, clarified by centrifuge, and refrigerated at $2^{\circ}($ : Aplpropriate dilutions were made just prior to rumiug the fyrosinaso assitys.

Tyrosinase was assityed speet rophotometricilly by measuring the optical density increase, at $390 \mathrm{~m} \mu$, of a mixture of cilcehol and enyyme in phosphate buffer. Techniques based upon the appratauce of eolorel oxidation products have not been entirely satisfactory $(62,5,2)$ because of a complex of faclors influencing color formation. In particular, the orthoquinome which is producel from atcehol alp)arently inactivates tyrosintse, althougth the oxidation rate is al lirst linear (29). Manometric techniques have been preferred by some workers $(32,3 l, 49,36)$, although smith and

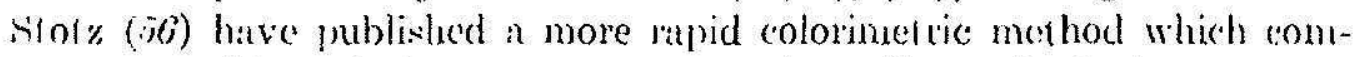
pares fivorably with the manometric procedures. Probably the best lyosinase asiays available are the chronometrie procedures of Dawson and allagee (23), and those of Miller al al. (47), in which orthorgunone is reduced back to ratechol by ascorbic acid as soon as it is tumed. The procedure adapted for cane fyrosinase is satisfactorily precise within a reation period of 2

living tissues no reasonable line ean be drawn fo separate arbohydrate breakdown from respiratory palliways.

${ }^{8}$ Tyrosinase was also extructed from leaves -1 and 0 , leaves +2 and +3 , leaves +6 and +7 , sheatlis +6 and $+7,8$ to 10 nodes, 8 to 10 internodes, nodss 1 to 3 , and intermodes 1 to 3 .

"The letter $\mathrm{N}$ is used throughout this paper as an ablureviation for the word "molat:" 
minutes, aud permits the handling of a very large number of sugareane samples.

The standard tyrosinase assaty was conducted at $20^{\circ} \mathrm{C}$. ancording to the lollowing procedure: $1.5 \mathrm{ml}$. of $0.1-\mathrm{Ml}$ phosphate buffer, pll 7.2, was placed in duplicate 1-f'm. pyrex cuvettes, followed by $0.5 \mathrm{ml}$. of eazyme preparation. About 2 or 3 units wore added to ench cuvette. One millilitor of distilled water was added to the veterence vessel and the optical deusity realing for this solution was adjusted to \%ero. One milliliter of 0.0 ir-.ll atcehol solution was then added to the test ruvette, optical densily of the tost solution was recorded, and a stopwatch was started inmediately. lReadings were again taken for hoth refrerenere and test solutions when 60

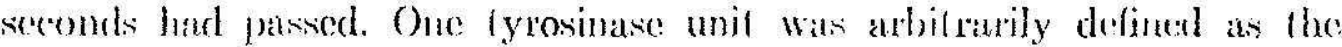
amount of suzyme anusing an oplical-density increase of 0.10 moder the preseribed anditions of the assily. Protein rontent of the (myyme propandions was deformined rolorimetrially by the mollod of sulherland ol al. (bl), and tyrowinase action was expressed as specific andivily in units fre milligram of protein.

\section{RESI LTS AND DISCUSSION}

\section{EXTHATNON, FRACEONATON, AND DISTRLBLTON}

Preliminary extraction trials for powdered, frecke-dried lad risstes were

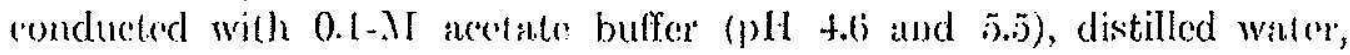
0.1-.) phosphate buffer (p) 7.0 and 7.5 ), and with 0.1 -1I tris buffer (trishydroxymethylamino nethane) of $\mathrm{pH} 8.0$ and $8 . i$. Acetale bufter

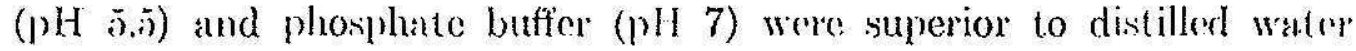
with regard both to total protein and tyrosinase obtamed. Phosphate buffer (pH 7) was used throughout the remainder of the study.

fractionation of the canc-leaf extracts revealed that lyrosinase was heavily precipitated over an unusually broad safuration range, from 25 to 70 percent (fig. 1). Only (Q enzyme (f), starch phosphorylase (5), and an $\alpha$-anylase (f) have previously been precipitaled so readily ab low-salt concentrations, and none of these was oblained over surh a broad salurat. ton range. Since protein is salted out when the protein-protein interaction begins to exeed the protein-waler interaction, a tremendous variation must exist among cane proteins having tyrosinase activity, particularly with regard to $-\mathrm{NH} 3^{+}$and $-\mathrm{COO}^{-}$groups. It seems probable that the protein requirement of tyrosinase is far less specific than that of the copper cofactor.

Distribution of tyrosinatie within the plant was ascertained with a series of tissue samples taken from 10-mouth old cane of the vitriety Uba Marot (table 1). By fax the greatest specific ativity was reoded with meristem prepations, with relatively slong atetivity also present in laves -1 and 
0. On a basis of achivily in units per gram of dried tisue, meristem completcly overshadowed all other tissues tested. This is not surprising in view of the rapid darkening of cane meristematic tissue observed whenever

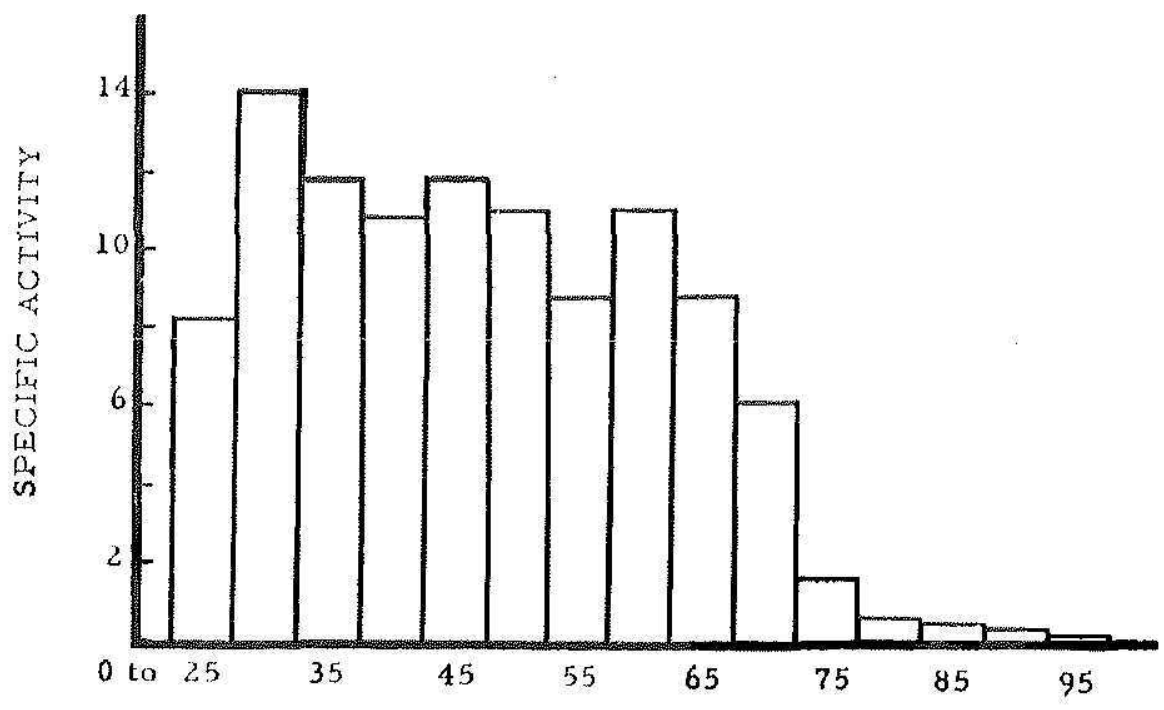

PLRCENT SATURATION BY AMMONIUM SULEATE

Fati. 1.-Tyrosinuse activily amoug protein increments presipitaled from extracis of sugatcane meristem.

TavLs 1.--Activity of tyrosinase extracted from different tissues of 12-monih-old sugarcane ${ }^{\star}$

\begin{tabular}{|c|c|c|c|c|c|c|c|c|c|}
\hline \multirow[b]{2}{*}{ Data classification } & \multicolumn{9}{|c|}{ Data for indicated tissue source -- } \\
\hline & $\begin{array}{l}\text { Meri- } \\
\text { stem }\end{array}$ & $\begin{array}{l}\text { Leat } \\
(-1 \\
\& 00)\end{array}$ & $\begin{array}{l}\text { Leal } \\
(+2 \\
k+3)\end{array}$ & $\begin{array}{c}\text { Leaf } \\
(++6 \\
\alpha+7)\end{array}$ & $\begin{array}{l}\text { Sheath } \\
(+6 \\
8+7)\end{array}$ & $\begin{array}{l}\text { Node } \\
(8-10)\end{array}$ & $\begin{array}{c}\text { Internole } \\
(8-10)\end{array}$ & $\begin{array}{l}\text { Node } \\
(1-3)\end{array}$ & $\begin{array}{c}\text { Tnternode } \\
(1-3)\end{array}$ \\
\hline Sipecific acilivily & 148.2 & 29,4 & 12.5 & 10.5 & 9.6 & 2.2 & 1.9 & 1.8 & 3.6 \\
\hline $\begin{array}{l}\text { Tyrosinase units per' } \\
\text { grim of tissue }\end{array}$ & 2075.0 & 122.0 & $(i 1.3$ & 49.4 & 32.2 & 3.5 & Traee & Trace & Trace \\
\hline
\end{tabular}

1 All reations were run for 2 ninutes al $20^{\circ} \mathrm{C}$. in phosphate buffer (pII 7.3). Catechol concentration was $0.1 \mathrm{M}$.

it is cut or damaged. Even freeze-dried meristem samples, initially white, totally dry and stored at $-10^{\circ} \mathrm{C}$., slowly turn brown with the passage of a few wecks. This is undoubtedly the work of tyrosinase acting upon endogenous phenolic compounds, uninspiring as these conditions must be for the catalyst. 


\section{Stability}

Unlike eane peroxidase (6), tyrosinase showed no resuperative rapacity after having been inactivated by boiling. Dialysis of the fyrosinas prepuration against distilled water caused a 23 -perent artivily decline within? hours (table 2), although activity gradually increased to its formor lovel by 32 hours. The dialysis offect is difficult to axplain, although obviously

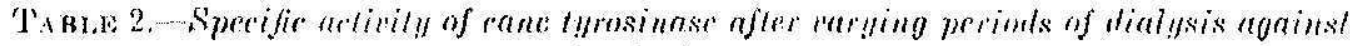
distilled wale,

\begin{tabular}{|c|c|c|c|c|c|c|c|c|}
\hline \multirow{3}{*}{ Data chassification } & \multicolumn{8}{|c|}{ Dita for inlicated dialysis time (hours) - . } \\
\hline & & & & & & & & \\
\hline & 0 & $1 / 2$ & 2 & 4 & $y$ & {$[6$} & 24 & 32 \\
\hline Specific netivity & 15.1 & 12.9 & 11.6 & 11.9 & 12.7 & 13.9 & 1.1 .5 & 15.2 \\
\hline
\end{tabular}

${ }^{1}$ Hinzyme samples were dialyzed at $2^{\circ} \mathrm{C}$. for the indicated period of time. Afterward they were stored at $2^{\circ} \mathrm{C}$. until the 32 hour trentment had been completed. Fach sample was then assayed according to the standard procedure.

TAm, 3.--Specific astivity decline of cane tyrosinase stored at room, laboralory, and rojrigerator temperatures ${ }^{1}$

\begin{tabular}{|c|c|c|c|c|c|c|}
\hline \multirow{2}{*}{ Storage temperature } & \multicolumn{6}{|c|}{ Data fot indicated days following preparation-.. } \\
\hline & 0 & 1 & 2 & 4 & 8 & 12 \\
\hline Room $\left(28-29^{\circ} \mathrm{C}.\right)$ & 15.1 & 3.4 & 1.1 & 0.5 & 0.3 & 0.2 \\
\hline Laboratory $\left(19-21^{\circ} \mathrm{C}.\right)$ & 15.1 & 5.6 & 2.5 & 1.1 & .8 & (i) \\
\hline Refrigerator $\left(2^{\circ} \mathrm{C}\right.$. $)$ & 15.1 & 11.9 & 11.1 & 9.2 & $5 . \bar{i}$ & $1.1 \mathrm{i}$ \\
\hline
\end{tabular}

1 Standad assay promelures were employed. Tyrosinase prepanalims wor stored under toluene.

no essential cofuctor was involved. Apparently bolh a potential artivalor and an inhibitor were present in the crude preparation, the former being more quickly removed by dialysis than the latter.

Stability of the tyrosinase preparation was to ted al several storage temperatures, including room $\left(27-29^{\circ} \mathrm{C}\right.$.), laboratory $\left(19-21^{\circ} \mathrm{C}.\right)$, and refrigerator $\left(2^{\circ} \mathrm{C}\right.$.). All samples were stored under toluene. As indieated in table 3, the preparations were extremely sensitive to room and laboratory $1 \mathrm{~cm}-$ peralures, losing about 77 and 63 pereent of their initial activity, respectively, within 24 hours of extraction. Samples stored at: $2^{\circ} \mathrm{C}$. deteriorated more slowly and tyrosinase was easily measurable after 12 days. This 
response to rool femperat ture conf rasts matkedly with sugateane peroxidase, the latler enayme declining more rapidly in the refigerafor than when standing in the liboratory.

\section{Optimum Temperature and pH}

Cane tyrosinase was tested at temperatures ranging from $16^{\circ}$ to $22^{\circ} \mathrm{C}$. Since no satisfactory method is available for rogulating temperatures of lest solutions within the spectrophotnmeter mployed, the following procedure was adapted: Duplicate test tubes containing all components of the standard digest except substrato were ecpuilibrated for is mimutes in a water bath adjusced to the desired temperature. Caterhol solution was equili-
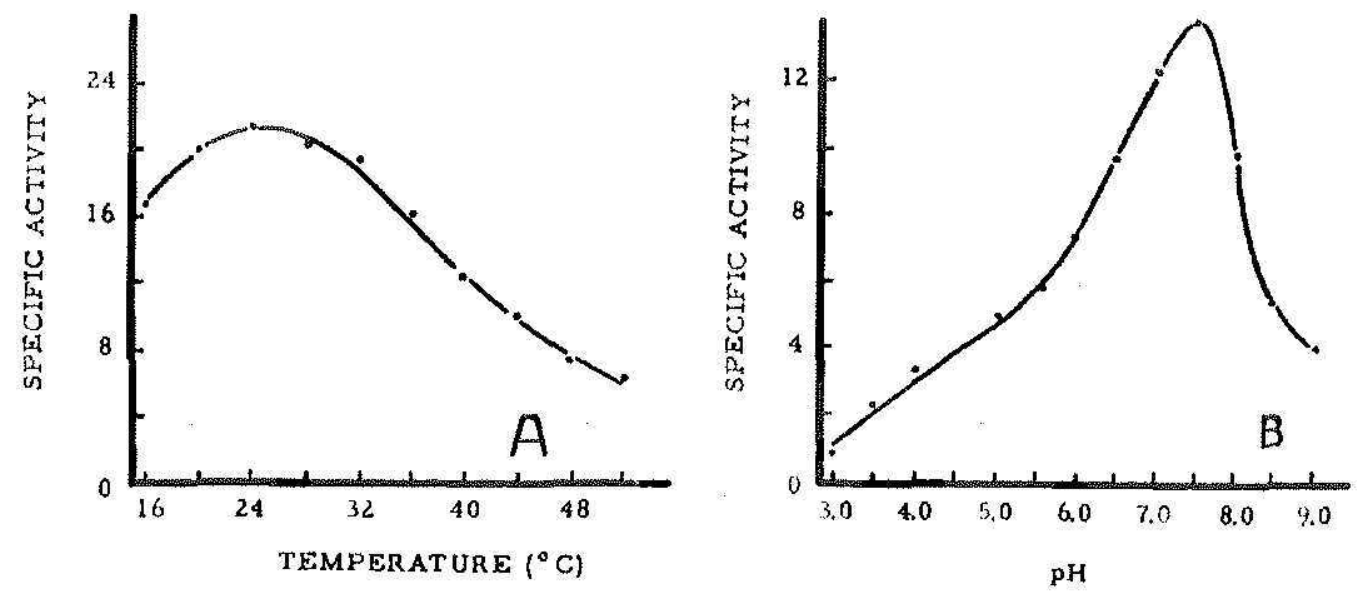

Fic. 2,- $\Lambda$, Effects of temperature on cune tyrosinase activity; B, effects of variable pH. Bulfers $(0.1 \mathrm{M})$ were employed as follows: Acetate, pH 3.5-5.5; phosphate, p) I 6.0-7.5; and tris (trishydroxymethylamim methane), $\mathrm{pH}$ 8.0-9.0. The stamblum atsaty was used throughout in conjunetion with the indieated variables.

brated sepuralely. One milliliter of distilled water was placed in the control tube and the reaction was then initiated by transferring $1 \mathrm{ml}$. of catechol solution to the test vessel. Two minutes were allowed for the reation to proced. Contents of the test lubes were rapidly transferred to $1-\mathrm{r}^{\mathrm{m}} \mathrm{m}$. ruvelter where optical-density diflerences between reference and test rolutions were measured as usual. About 2 minutes and 15 seconds elapsed for euch rection. Although some error was unavoidable, the results were nevertheless relative, and indicated that optimum temperature for cane tyrosinase is about $24^{\circ} \mathrm{C}$. (fig. $2, \mathrm{~A}$ ). Thus, quite by accident, the laboratory temperature we ordinarily employed was very near optimum. Dawson and Magee (23) recommended $25^{\circ} \mathrm{C}$. for both "cresolase" and "catecholase" assays, whercas Smith and Stotz $(56)$ suggested $30^{\circ} \mathrm{C}$. for colorimetric measurement of general plant tyrosinase. Peroxidase of sugarcane wats 
more than twice as active at $36^{\circ} \mathrm{C}$. than at the $20^{\circ} \mathrm{C}$. temperature where it was ustully measured.

Optimum phe for and Iyrosintse was about 7.5) (fig. 2,13). This cortesyonds alosely with the optimum ple for "ane peroxidatse (7.t), yet was higher than that recommended by Dawson and Magee for " "resolate" $(7,0)$ and "calecholase" (j.l), or by Miller et al. for general tyrosinatse (j,j). Smith and stoty lound "wlochol oxidane" (polato) to be considerably less artive at pH 4.5 than at higher pH values, but observed litle difterence between pll 6.0 and 7.5 .
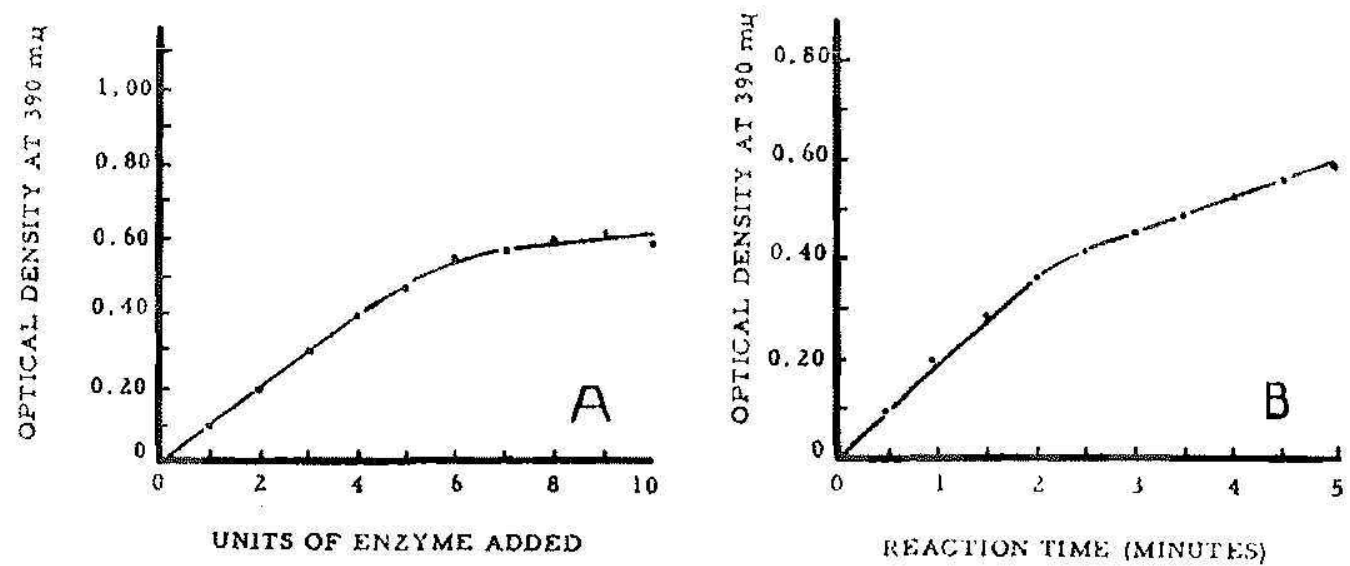

Fixa. 3.-A, Proportionality of tyrosinase activity with concentration; B, proportionality of activity with time. There were 2.5 units enployed for the time experiment, otherwise the standard assay was used throughout in conjunction witl the: indicated variables.

\section{Reation Velocity vs. Kinzyme: Conecntration and T'ime}

A linear relationship exists between reation velocity and tyrosinase content to a conentration of $j$ units per digest (fig. $3, \lambda$ ). Ordinarily, about 2 to 3 units of enzyme were employed for the standard tyrosinase assay.

Orhoquinono is generally regarded as an inhibilor of tyrosinase when the enzyme acts upon catchol $(60, p) .242,36,19,23)$. In some instauces it has even been found neressary to add ascorbic areid to the extracting media in order to redure quinones formed from codogenous phenolic compounds, and thereby to prevent tyrosinase inhibition while the cuzyme is being prepared (56). A major concern with cane tyrosinase was the development of rapid procedures whereby large numbers of samples rould be preprared and assayed in a single day. Consequently, it was necessary to determine for how long the direct oxidation of catechol could be regarded as a reliable measure of tyrosinase action (i.e., until quinone began to inhibit). As indicated in figure $3, B$, the enzyme obeycr a linear reaction for only 2 min. 
utes, which, nevertholess, sufficed for establishing a standard assay based upon a 60-second reaction period.

Substrate Concenlrution, $K \mathrm{~m}$.

Cane tyrosinuse was lested with catechol concentrations ranging from 1 10 $50 \mu \mathrm{mols} / \mathrm{ml}$, of cligest. (fig. 4). Maximum velocity was recorded with 8 $\mu$ mols of catcehol. $\mathrm{Km}$ is therefore about $4.0 \times 10^{-3}$ mols of catechol per lifer.

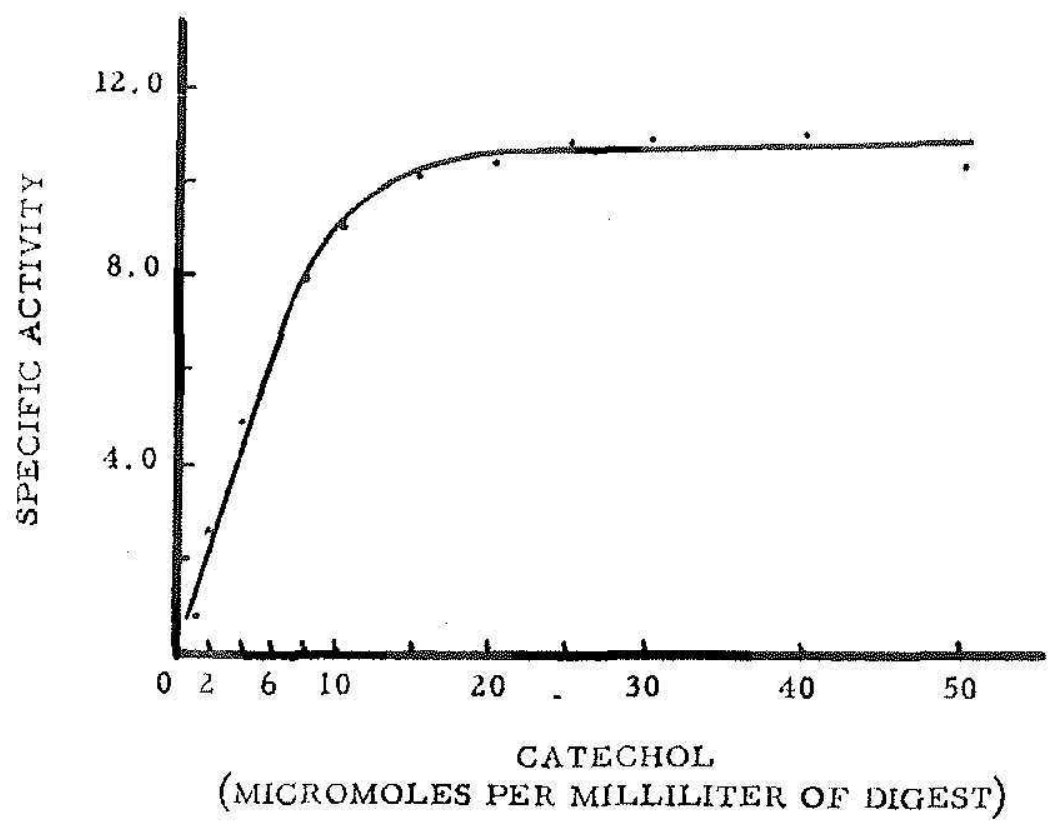

Fut f, - liffects of varibble subst rate concentration on the activity of tyrosinase from solgatcane meristem.

\section{Siubstrale Specificily}

Tyrosinase will conceivably be found accompanied by such enaymes as peroxidases, anorbic: acid oxidase, and other phenol oxidases, ineluding lacease. Such enzymes might aller or modify tyrosinase action, particularly so when tyrosinase has been precipitated over an unusually broad saltsaluation range. Tyrosinase can be distinguished from laccase in view of its capacity to catalyze two distinct oxidations, the addition of a hydroxyl group into a monohydric phenol (ortho to the onc already present), and oxidation of orthodilyydric phenols to the corresponding orthoquinones. laccase can bring about the oxidation of both ortho- and paradihydric phenols, but does not act upon monohydric phenols.

Cane tyrosinase acted upon tyrosine, eatechol, DOPA (3,4-dihydroxy- 
phenylalanine), pyrogallol, guaiacol, resorcinol, hydroquinone, and paracresol. No reaction was detected against phonol or metweresol. The possibility camot be ruled out that Jacease (a true polyphenol oxidase) composes part of the cane tyrosinase preparation.

Cushing (22) has studied the effects of tyrosinase on a series of substituted phenols. Oxidation of complicated, high molen'ular-weight substances by tyrosinase has also been roported (ij).

\section{Actiration and Inhibition}

$A$ series of eal ions and anions were lested for powsible regulatory offects upon tyrosinase (table 4). Also bosted were glurose, cysteine, thiourea, hydroxylamine, and aseorbie ariel. Thiourea and hydroxylamine markedly

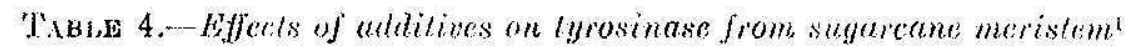

\begin{tabular}{|c|c|c|c|c|c|}
\hline Alditive & $\begin{array}{l}\text { Specific } \\
\text { tetivity }\end{array}$ & Additive & $\begin{array}{l}\text { Specific } \\
\text { activity }\end{array}$ & Addditise & $\begin{array}{l}\text { Sprecific } \\
\text { activity }\end{array}$ \\
\hline Control $\left(\mathrm{II}_{2} \mathrm{O}\right)$ & 11.3 & I & 12.1 & Bilucose & 10.8 \\
\hline $\mathrm{Ca}$ & 10.8 & $\mathrm{Cu}$ & 12.5 & Nitiate & 11.3 \\
\hline $\mathrm{Mg}$ & $11 . \dot{2}$ & As & 10.4 & Cystoine-ric) & 0 \\
\hline B & 9.0 & $1 / 11$ & 10.0 & Thisure: & (i. 1 \\
\hline li & 10.1 & (X) & n & Hydrexylaumine & 5.0 \\
\hline $\mathrm{Br}$ & 10). 8 & $\beta-(i)^{\prime}$ & 11.3 & 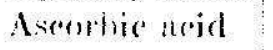 & () \\
\hline
\end{tabular}

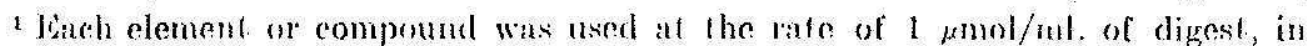

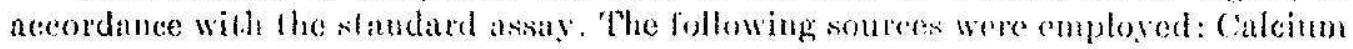

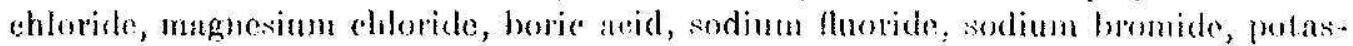

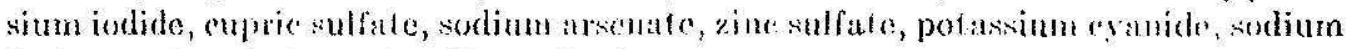
B-glyecrophosphate, and sodium nitrite.

inhibited the onyme at the rate of $1 \mu \mathrm{mol} / \mathrm{ml}$, of digest. Inhibition was virtually eomplete at 10 times this conentration. Cysteine and astorbic aeid permitted no metsurable arelivity, and (ytuide, also at the rate of 1.0 $\mu \mathrm{mol} / \mathrm{ml}$. of digest, allowed only a trace of tyrosinase arivity. Separate experiments showed the enzyme to be completely juhibited by carbon monoxide.

The inhibitory effects of thiourea, cyanide, and (yst eine were anticipaled from the review by Sumner and somers $(60,1), 2+2)$, although no mention was made of hydroxylamine at a tyrnsinase inhibitor. Curiously, hydroxylamine did inhibit cane peroxidase $\left(6^{6}\right)$, which prompled tis to test it on tyrosinase, and sumuer aud Somers do list it ats an inhibior of horseradish peroxidase $(60,1) 223)$.

The exsentiality of copperes a rofactor of cane tyrosinitso wits determined by the method of Kubowity (38), who originally demonstrated that 
this type of enzyme is a copper-protein. Kubbowitz could not remove copper by ordinary dialysis against water, but by inactivaling tyrosinase with ICX, he was then able to separate copper from the enzyme by dialysis against ruming water. The oxidase protein, still inactive after dialysis, could be reactivated by adding copper. Othor metals were not effective in restoring activity.

Cane tyrosinase which had been treated with $\mathrm{KCN}$ and dialyzed for 40 hours against distilled water lost all but at small fraction of the original achivity (table 5 ). An little as $0.2 \mu \mathrm{mol}$ of ('op)per per milliliter of diges suffeed to artivate the dialyzed enzyme 10 ahout 67 pereent of eomirol values, and 1 mol of copper refurned better than 100 pereent of the ch\#yme's origimal activity. None of the ofler metals or jonic substanese

Talls: 5.-Stimulating efects of copper on cane tyrosinase following inactination with potassium cyanidet

\begin{tabular}{|c|c|c|c|c|c|c|c|}
\hline \multirow{3}{*}{ Dita classiffeation } & \multicolumn{7}{|c|}{ Data for indicated treatment of tyrosinase prejarations } \\
\hline & \multirow{2}{*}{$\begin{array}{l}\text { Undialyzed } \\
\text { (control) }\end{array}$} & \multicolumn{6}{|c|}{$\begin{array}{c}\text { Dialyzed enzyne }+ \text { Cu at indicated concentrations } \\
\text { ( } \mu \mathrm{mol} / \mathrm{ml} \text { of digest })-\ldots\end{array}$} \\
\hline & & 0 & 0.2 & 0.1 & 0.0 & 0,8 & 1.0 \\
\hline Sperifir netivily & 23.7 & 1.9 & 15.8 & 20.2 & 22.2 & 24.8 & 25.9 \\
\hline
\end{tabular}

'Wherens control tyrosinse was prepared as usual with water, test preparations were made up in $0.025 \mathrm{M} \mathrm{KCN}$, which tolally inactivated lyosinase. The latter were dialyzed for 40 hours at $20^{\circ} \mathrm{C}$., against 5 changes of distilled water to separate cyanide and copper from the free protein. Standard assays were then run with undialyzed tyrosinase in water solution, and with dialyzed enyyne in the presence of copper addilives.

Iosterl as possible andivators (lable d) served to antivale the KCN-trouted (nzyme. The slight areivity remaining after the $K C X$ and dialysis treatments might be due to an iron-bearing enzyme such as peroxidase, or a noncopper-requiring oxidase in the tyrosinase prepatution.

SIGNIFIANCE OF TYROSINASE IN SLGARCANG

Having already mentioned the controversy as to whether tyrosinase or rylochrome oxidase is the responsible catalyst of terminal oxidation, it is obvious that one or the other must play an unusually significant role in sugareane as a key system in the pathway of sugar breakdown. At the moment we lool that tyrosimase must assume a pur of all of this role. The high incidence of tyrosinase in meristem tissues could hardly be an aceident, and previous efforts to deted cylochrone oxidase in rane have proven unstuecessful (l). 
Another possible function of tyrosimase in cane is that of an indirece oxidase for aseorbic acid. Inzymes which act apon phonols, including tyrosinase and peroxidase in the presence of hydrogen poroxide, form quinones which in ture may act upon ascorbic acid. Ascorbic arid might therofore serve as a reducing agent in the following tyrosintse-induced renction sequence:

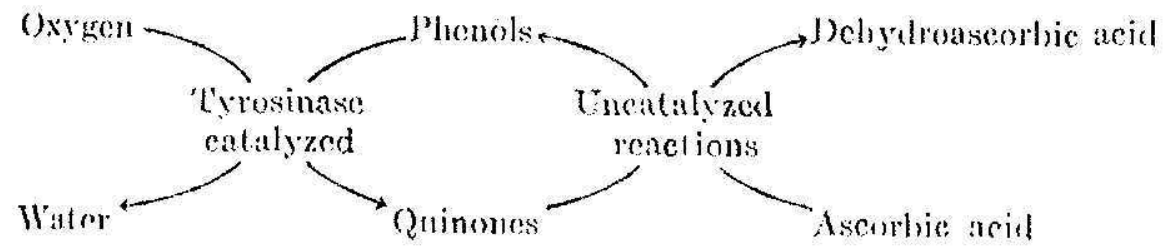

Some cvidence indieates that the enzyme ascorbie acid oxidase, which oxidizes the arid directly, may eatalyze elertron framser in respiration of higber plants $(39,60)$. 16 is probahle that a combination of tytosinase and ascorbic acid would aceomplish the same lask in tissues lawking ascorbir ineid oxidane.

A potentially critical function of tyrosinase might arise from the eapacily of this enzyme to oxidize the tyrosyl groups of proteius, as evidenced by the work of Sizer (55). Tyrosinuse did not affect the aclivily of the tyrosylbearing enymes pepsin, trypsin, and chymotrypsin, presumably because only a small fraction of the tyrosine was oxidized. Also meriting consideration is the work of James et al. (3.), which revealed a relationship between glycolysis and oxidation by the aseorbie acid system. Addition of ascortic: acid to barley preparations stimulated the loss of hexose diphosphate. Tyrosinase thus might affect sugar levels via its capacity to serve as an indirect ascorbic acid oxilase.

It is conceivable that direct use might eventually be nude of information concerning tyrosinase or its associated oxidases in eane lespiration. From time to time efforts have been made to regulate the sugar content of standing stgareane, or to prevent periodic sugar losses by applying materials bearing strong rapacity to alter the physiology of plant.s. Rerent examples include the use of 2,4 -dichlorophenoxyacelic acid $(11,10,41)$, maleie: hydrazide with sugarcatue $(1,2,3)$ and with sugar beet $(\delta 4)$, and indole-3acetic acid (3). Naleic hydrazide, as well as the chemicals CMU and Diquat, have been applied to foliage in order to evaluate the role of leaves in biorhemical processes of eane flowering (21). Oils have been used as foliar sprays to prevent seasonal sucrose losses $(50,25)$. The specific action of such materials is seldom lnown when they are applied, and usually it is hoped, without very much basis, that more desirable sugar or physiological objectives will somehow come to pass. In any event, the curtailment of respiratory mechanisms, of which the terminal oxidases are both critical and sensitive catalysts, appear as most likely areas for action of applied 
chemiculs. It is therefore probable that, when the propertices ol cance oxi-

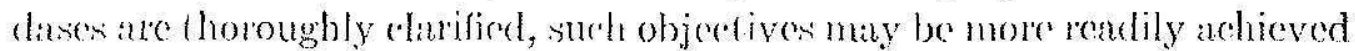
by use of enzyme regulators amed specificully at catalysts such as tyrosinase.

\section{SUMINARY}

d study was madr of the distribution and propert ies of tyrosinase (polyphenol oxidase) in sugartane. The rnzyme was extracted wilh phosphate

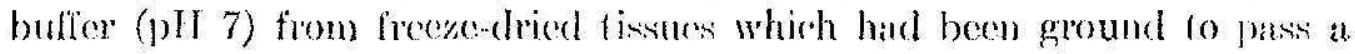
(i)-mesh sereen. Tyrosinase was assayed spectrophotomed rically at $300 \mathrm{~m} \mu$ by motsuring the optiral density increase of a butfered mixture of raterehol and enzymo.

Frationation of ane extatels with ammonimm sulfale showed that tyosinase is precipitated readily from 20. 10 70-perent saturation. The richest souree of the enzyme. was moristemat ie tissue. Considerable ardivity Was alse obtained from louves - 1 and 0 , whereas only traces of the enyyme were present iu hoth 8 to 10 and 1 to 3 uodes and incemodes.

Tyosinase meparations were hea-sensilive, losing most of their aclivily within 2t hours of extration at room lemperature $\left(28-29^{\circ} \mathrm{C}\right.$.) and labonatory temperature (19) $21^{\circ} \mathrm{C}$.). In contast to anc peroxidate, no reruporative rapateity was evident afue inaclivation by boiling.

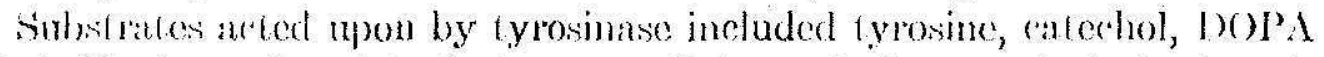
(3, 4-dihydroxyphenylalanine), byrogallol, guaicol, resoreinol, hydrocjuinone, and pararesol. No reaction was observed with phenol or metaresol. Optinum tempenture was about $24^{\circ} \mathrm{C}$, and optimum $\mathrm{pH}_{\mathrm{H}}$ was 7.5 . Apparent $\mathrm{Km}$ was $4.0 \times 10^{-3}$ mols of ealechol per licer. Thiourea and hydroxylamine markedly inhibited the enzyme at concentrations of $1 \mu \mathrm{mol} / \mathrm{ml}$. Cysteme, ascorbic acid, and cyanide caused virtually complete inhibition at this concentration. Carbon monoxide likewise inhibited.

Tyrosinase which was inativated by $\mathrm{KCN}$ was reactivated following prolonged dialysis against distilled water and addition of copper. No other metal tested (molybdenum, manganese, zinc, iron, magnesium) served to retulivate the calalyst.

Possible roles and signifimane of cane lyrosinase are discussed.

\section{RLSUMEN}

So hizo un estudio de la distribucion y propiedades de la tirosinasa (oxidasa de polifenol) en la caña de azúcar. La enzima se extrajo con un amortiguador de fosfato ( $\mathrm{pH}$ 7.0), de tejidos secados por congelación que se trituraron hasta poder pasarse por una criba de mallas, tamaño 60. La prucba se hizo en un espectrofotómetro a $390 \mathrm{~m} \mu$, midiéndose el aumento en densidad óptica de una mezcla amortiguada de catecol y enzima. 
Al separarse por fraccionación los extactos de la cana con sultato amónjeo, se precipito la tirosinasa lácimente entre una saluración de 20 a 70 por ciento. En el tejido meristomático fue que se cncontró la mayor cantidad de la enzima. También se consignió una actividad considerable en las hojas - 1 y 0 , mientras que sólo se cucontraron trazas de la enzima en los mudos y entrenudos del 8 al 10, y del 1 al 3 .

Las preparaciones de tirosinasa se mostraron sensitivas a la acción del ealor, inactivándose ensi lolalmente a las 24 horas despues de haberse extraido a una tempentura smbiental de 28 a $29^{\circ} \mathrm{C}$ y de 19 a $21^{\circ} \mathrm{C}$. en el laboratorio. Fin contraste eon lo che sucede ron la peroxidasa de la cana, la tirosimasa no evidenció anateidad recuperativa despues de la inadividad que le cussura hervita.

Los siguientes fueron los sustratos sobre los cuales actuó la tirosinasa: catecol, DOPA (3,4-dihidroxifenilalanina), pirogalol, guayacol, resoreinol, hidroquinona y para-cresol. No se observó renceión alguma con el fenol o con el metacresol. La temperatura óptima fue de alrededor de $24^{\circ} \mathrm{C}$. y el pH óptimo 7.5. Fl $\mathrm{Km}$ aparente fue $4.0 \times 10^{-3}$ moles de eatecol por litro. Ia tiourea y la hidroxilamina inhibicion la chima maradamente a conrontraciones de $1 \mu \mathrm{mol}$ por mililitro de digesto. Ia cistcíma, el ácido ascórbico y cl cianuro causaron una inhibicion casi completa a tal roncentrarión. St monóxido de carbouo atouó de igual manera.

la tirosinasa indetivada por KCN se reactivó tras una diálisis prolongada. en presencia de agua destilada seguida por la adición de cobere. Ninguno de los otros metales que se probaron (molibdeno, manganeso, zinc, hicro, magnesio) sinviexon para reachivar el agente catalizador.

So discute en este trabajo la posible función que pueda ejerer la tirosinasa y la importaneia que jueda tener en la caña de azúcar.

\section{M.ITERA'TURE CITEI)}

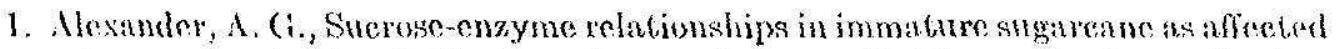
by varying levels of nilatio and potassium supplied in sind culture, $/$. Agr. Univ. P.R. $48(3): 105-231,1964$.

2.--- Whicets of varying mutrient levels on growth and enzymo activity of eatiflower; thessis submitted to the Faculty of the Graduate Seheol of the University of Maryland in partial fulfilment of the requirements for the degree of Doctor of Philosophy, 1960.

3. - Changes in leat-sugar eontent and enzyme activity of immature sugareane following foliar application of indole-3-acetic acid, 2,4-dicholorophenoxyacetic aed, and maleic hydrazide, $J$. Agr. Univ. P.R. 49(1): 1-34, 1965.

4. - Hydrolytic proteins of stgareane: 'The Q enzyme, J. Agr. Univ, P.R. 49(2): $176-203,1965$.

5. - - The biosynthesis of stareh in sugareane, Proe. R.S.S.C.T., (in press) 1965.

6. - The oxidizing enzymes of sugarcane: Peroxidase, J. Agr. Univ. P.R. 50(1): 36-52, 1966. 
7. Allon, P. J., and (ooddard, D. IR., A respinatony study of powdery nuildew of whent, Amer. J. Bot. 25: 61:3-21, 1938.

8. Amon, D. I, in Molioy, W. D., and Glass, (i., Copper Metabolism, a symposium on animal, plant and soil relationships, The Johns Ilopkins Press, Baltimore, Md., pp. 80-114, 1950.

9. Baker, D., and Nelson, J. M., Tyrosinase and respiration, J. Gen. Physiol. 26: 260-74, 1943.

10. Bailey, L. I', and McHargue, J. S, Fffect of boron, copper, manganese, and zinc on the enzyme activity of tomato and alfalfa plants grown in greenhouse, Plant Physiol. 19: 105 16, 1944.

11. Benuchamp, C. Ji, Effects of 2,4-D) on sugar content of sugarcanc, Sugar, J. 13(5): $67-70,1950 ; 13(3): 2030,1950$.

12. Bertrand, (․, Compt. Rend, 121: 166, 1805; see referenee 49, p. 100.

13. -- Compt. Rend. 122: 1215, 1896; see reference 49, p. 100.

14. Bonner, J., and Wildman, s, Gi, Enzymatic meshanisms in the respiantion of spinach leaves, Atch. Biochem. 10:497-518, 1940.

15. Bourquelot, E., and Berimul, G., Compl. Rond. Soc. Biol. 47: 582, 1895; sen xoforence 49, pp. 100-101.

16. Buswell, J. G., and Whiting, G. C., A study of the polyphenol oxidase system in potato tubers, Am. Bot., N. S., 2: 847-9, 1938.

17. Brown, A. H. and Goddard, D. R., Cytochrome oxidase in wheat embryos, Amer. J. Bol. 28: 319 24, 1941.

18. Brown, J. C., and Steinberg, R. A., Tron and copper enzymes in leaf lamina of tabaces when deficient in micronutrients or grown on enteareous and organic soils, Illunt l'hysiol. 29: 188-94, 1952.

19. Brown, J. G, and Fendricks, S. B., Finymatic activities as indications of eopper and iron deficiencies in plants, Plant Physiol. 27: 651-60, 1952.

20. Brown, J. C., The effect of the dominance of a metabolic system requiring iron or copper on the development of lime-indueed chlorosis, Plant Phystol. 28: 495$502,1952$.

21. Coleman, R. E., Pliysiology of Flowering, Fawaii Sugar Technol. Reports pp. 108-9, 1963.

22. Cushing, M., The oxidation of eatechol-type substrates by tyrosinase, $r$. Amer. C,hem. Soc. 70: 1184-7, 1949.

23. Datson, C. R., and Magee, R. J., Plant tyrosinase (polyphenol oxidlase), Methods in kinzymal. 2: 817-27, 1965.

24. Dawnon, C. R, and Tarpley, W. 13., in Summer, J. G., and Myrhack, K., The Euzymes, Chemistry and Mechanisms of Aetion, Acarlemic Press, Inc., New York, N.Y., 2(1): 45.1-98, 1951.

25. Iolfel, N. E., Calbuillas, E., and Ortiz-Torres, E., A small-scale techniqune for evaluation of the effect of spray oils and other materials on sugarcane yields, J. Agr. Liniv, P.R. 46: 328-33, 1962.

26. Lichel, B., Waino, W. W., Person, P., and Cooperstein, S. J., A partial separation and characterization of cytochrome oxidase and cytochrome b, J. Biol. Chem. 183: 89-103, 1950.

27. Fruton, J. S., and Simmonds, S., Gencral Biochenistry, 2nd ed., John Wiley \& Sons, Ine., New York, N.Y., 1963.

28. Goddatd, D. R., and Meeuse, B. J. D., Respiration of higher plants, Ann. Rev. Plant Physiol. 1: 207-32, 1950.

29. Gould, B. S., Animal and plant tyrosinases: Oxidation of mono- and dihydric phenols as a function of temperature, Enzymologia 7: 292-6, 1939. 
30. Graubard, M., Vterine respiration, cytochrome oxidase and oopper, Amer. $J$. Plysiol. 131: $5848,1941$.

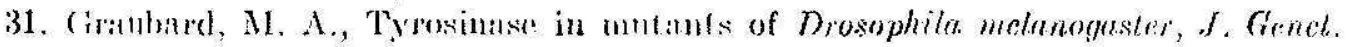
$27: 199218,1933$.

32. Cimuluad, M. d, and Nelson, J. M., Tymusiuase action on numb-and dihydric subst.rates, , B. Biol. Chem. 111:757-70, 1935).

33. Guzman Bamron, L. S., Iaik, (․ K. K., Klein, R. M., and Michol, B. E., 'The motabolism of potitu slicrs, Areh. Bionthem. 28: 377.98, 1950.

34. James, W. O., Heart, O. R. (., and Junes, ( 1 . W., The oxidative decomuesition of hexose diphosphate by barley, the role of aseorbic acid, New Phytol 43: 62-74, 194.

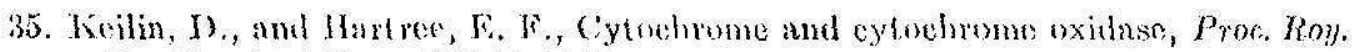
Sor. (London) B $127: 167-91,1939$.

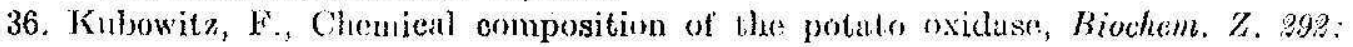
$2219,1937$.

37. - Cloavage and resyuthesis of polyphenol oxidase and of hemocyanin, Biochem. \%. 299: 32-57, 1938.

38. --., Resynthesis of phenoloxidase from protein and copper, Biochem. Z. 296 : $4434,1938$.

30. Levy, H., Sehade, A. L., Bergmann, L., and Farris, S., Studies on the respiration of the white potato, Arch. Biochem. 19:273-86, 1918 .

10. Loustalot, A., (iruzado, H. J., and Muzik, 'Г. J., The efleet of 2,4-1) on the sugar content of sugarcane, Sugar J. 13(5): $78,1950$.

41. Lugo-López, M. A., and Grant, R., Preharvest foliages sprays of sugareane with 2, 4-D, J. Aqr. Vniv. P'.R. 36:187-93, 1952.

12. Lngo-lópez, M. A., Sammels, Ci, and (irunt, R., Fuilure of prolurvest foliuge sproys with $2,4-0$ and maleic hydrazide to affect the sucrose content of sugarcane. I. . Igr. Univ. P.R. $37(1): 4151,1953$.

43. Marsh, P. B., and cioddard, D. R., Respiration and fermentation in the carrot, Daucus curolu. I. Respirtion, Amer. J. Bot. 26: 724 \&, 1939.

4. Mason, H. S., 'The chemistry of molanin, III, Mechanism of the oxidation of dihydroxyphenylalanine by tyrosinase, f. Biol. Chem. 17: 83-99, 1948.

45. - - The chemistry of melanin, IT, The oxidation of dihydroxyphenylatanine by mimmalian DOPA nxidase, $\%$. Biol. Chem. 168: 433-8, 1947.

16. Mason, H. S., and Wright, O. I., The chemistry of melanin, V, Oxidation of dihydroxyphenylalanine by tyxosinuse, $J$. Biol. Chem, 180:235 47, 1949.

47. Miller, W. H., Mallete, M. F., Roth, I. F., aud Dawson, C. R., A new method for the mea sumenent of (yrosinase catecholase activity, II, Catecholuse activity based on the initial reaction velocity, $J, A$ mer. Chem. Sor. $66: 5149,1944$.

18. Nelson, J. M., in MeGlroy, W. D., and Glass, B., Copper Metabolism, a symposium on animn, plant and snil relationships. The Johns Jopkins Press, Baltimore, pp. 76-88, 1950.

49. Nelson, J. M., and Dawson, C. R., Tyrosinase, Aduances in Enzymol. 4: 99 152, 1944.

50. Personal eommunication between Dr. N. E. Dellel, Chemist, Federal Fxperiment Station, Agricultural Resenrch Service, USDA, Mayngüez, P.R., and Dr. H. Guijot, of I.F.A.C., Giuadeloupe, F.W.I.

51. Ponting, J. D., and Juslyn, M. A., Ascorbic acid oxidation and Browning in apple tissue extracts, Arch. Biochem. 19: 47-63, 1948.

52. Raper, H. S., in Bamann, E., and Myrback, K., Dic Methoden der Fernentforselung, G. Thieme, Leipzig, Germany, p. 2476, 1941. 


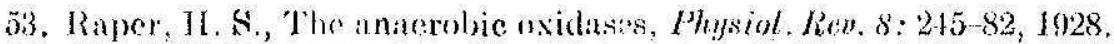

51. Ririe, 1)., and Nikkelson, 1). S., The effect of nuake hydrazide on sugar beet

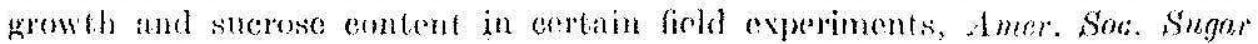
Brot Techol., ithstracts, Foh, 1902.

55. Sizer, 1. W., Thr action of tyrosinatse on proteins, .J. Biol. Chem. 163: 145-57, 19).ti.

56. Smith, F. (i, and Stok, F, A colorimetrie method for the determination of phenol oxidase in plant material, $J$. Biol. Chem. 179: 865-80, 1949.

57. Sommer, A. L., Copper as an resculial for plani growth, Plant Physiol. 6: 339-45, 1931.

58. Sreenugachar, H. B., Studies on the 'termentation' of Ceylon tea, 6, The nature of the teatexidese system, Biochem. J. 37: 661-67, 1943.

59. --.-. Studies on the 'Termentation' of Ceylon lea, 5, comparative mas of oxidation of diflerent polyphenolic substanees by tea-oxidizing enzymes, Biochem. J. $37: 656 \cdot 60,1943$.

(60). Summer, J. B., aud Sommers, C. F, Chemistry and Methods of Enzymes, 3d. ed., Acudemic Press Inc., Now York, N.Y., 1953.

61. Sutherland, J:. W., Cori, C. L'., Haynes, R., and Olsen, N. S., Purification of the hyperglyeenic-glyeogenolytic factor from insulin and from gastric muensa, J. Biol. (Hem, 180: 825-33, 19:19.

62. Suttor, H., Polyphenol oxidase, kryeb. Linaymforsth, 5: 273 84, 1936.

63. Szent-Gyorgyi, A, V., On Oxidation, Fermentation, Vitumins, Mcalth, and Dis(:tse, Williams \& Wilkins, Baltimore, Mal, 1939.

64. Warburg, O, Gelwometalle als Wirkungsgruppen Vol Firnenten, 2nd. ed., Berlin, p. $154,1948$.

65. Waygood, E. R., Physiological and boghemieal studies in plant metabolism, II, Respiratory enzymes in wheat, Can.J. Res. (28: 7-62, 1950. 